\title{
Tomasz Jakubiak
}

\section{Nadzwyczajna forma zawarcia małżeństwa według Kodeksu Prawa Kanonicznego z 1917 i 1983 r.}

Ius Matrimoniale 25/2, 43-62

2014

Artykuł został opracowany do udostępnienia w internecie przez Muzeum Historii Polski w ramach prac podejmowanych na rzecz zapewnienia otwartego, powszechnego i trwałego dostępu do polskiego dorobku naukowego i kulturalnego. Artykuł jest umieszczony w kolekcji cyfrowej bazhum.muzhp.pl, gromadzącej zawartość polskich czasopism humanistycznych i społecznych.

Tekst jest udostępniony do wykorzystania w ramach dozwolonego użytku. 


\title{
Ks. Tomasz Jakubiak \\ Papieski Wydział Teologiczny w Warszawie
}

\author{
Nadzwyczajna forma zawarcia małżeństwa \\ według Kodeksu Prawa Kanonicznego \\ z 1917 i 1983 r.
}

\section{Historia rozwoju instytucji nadzwyczajnej formy zawarcia malżeństwa ${ }^{1}$}

Do Soboru Trydenckiego dla ważności zawieranego małżeństwa nie wymagano od katolików żadnej formy jego celebracji ${ }^{2}$. Duże zmiany w tym zakresie przyniósł dekret Tametsi z 1563 r., uchwalony w czasie Soboru Trydenckiego. Ojcowie soborowi postanowili, że „ci, którzy będą usiłowali zawrzeć małżeństwo w inny sposób niż w obecności proboszcza albo innego kapłana (za zgodą samego proboszcza albo biskupa ordynariusza) oraz dwóch albo trzech świadków, są całkowicie niezdolni do zawarcia takiego małżeństwa, a tego rodzaju związki sobór uznaje za nieważne i żadne, jak również niniejszym dekretem unieważnia je i znosi"’.

Życie okazało się jednak bardziej skomplikowane niż przewidział to ustawodawca. Znalazły się bowiem takie miejsca, gdzie z powodu trudności dostępu do kapłana mogącego pobłogosławić związek małżeński, zachowanie jedynej przepisanej przez dekret Tametsi for-

${ }^{1}$ Niniejszy podpunkt stanowią fragmenty artykułu: T. JAKUBIAK, Poczatki prawa regulującego nadzwyczajna formę zawarcia matżeństwa, Warszawskie Studia Teologiczne XXVI/1/2013, s. 207-218.

2 Por. A. Sarmiento, Małżństwo chrześcijańskie. Podręcznik teologii matżeństwa i rodziny, Kraków 2002, s. 172.

3 Sobór Trydencki, Sesja 24, 11.11.1563, w: A. Baron, H. Pietras (opr.), Dokumenty Soborów Powszechnych. Tekst grecki, łaciński, polski, t. 4, Kraków 2005, s. 723. 
my zawierania małżeństw przez katolików - okazywało się niemożliwe. W takiej sytuacji kanoniści zostali zmuszeni do uznania przewagi prawa naturalnego osoby do zawarcia małżeństwa nad prawem pozytywnym, także tym stanowionym na soborze. W dekrecie $\mathrm{z}$ dnia 26 września 1602 r., zatwierdzonym przez papieża w 1603 r., znalazła się norma dopuszczająca ważne zawieranie małżeństw w obecności dwóch świadków - w regionach, w których występował brak kapłanów albo tam, gdzie musieli się oni ukrywać z powodu prześladowań religijnych. Niezachowanie formy dopuszczone było jedynie w określonych sytuacjach, w których występował fizyczny brak kapłanów. Zgodnie z normami zawartymi w dekrecie Świętego Oficjum z dnia 1 lipca 1863 r., można było zawrzeć małżeństwo bez obecności kapłana, jeśli przewidywało się, że będzie on nieobecny przez miesiąc ${ }^{4}$.

Kompleksowe uregulowanie nadzwyczajnej formy przyniósł dekret Ne temere. W jego punkcie 7 zapisano, że w bezpośrednim niebezpieczeństwie śmierci, kiedy proboszcz, ordynariusz miejsca bądź delegowany przez nich kapłan był nieosiągalny, dla uspokojenia sumienia oraz jeśli sprawa tego wymagała, legitymizacji dziecka, małżeństwo można było ważnie i godziwie zawrzeć przed jakimkolwiek kapłanem wobec dwóch świadków ${ }^{5}$. Według przepisu zamieszczonego w punkcie 8 wspomnianego dekretu, jeśli zdarzyłoby się w jakimś regionie, że kapłan lub ordynariusz miejsca lub kapłan delegowany przez nich, wobec którego małżeństwo może być celebrowane, jest nieosiągalny i stan ten trwa już miesiąc, małżeństwo może być ważnie i godziwie zawarte przez formalną zgodę małżonków w obecności dwóch świadków .

${ }^{4}$ Por. Sacra Congregatio Sancti Officil, Ad Episc. Vailis pranensem, 01.07.1863, w: K. Gennari, Nowe prawo kościelne o zaręczynach i o matzeństwie, tł. A. LeCHert, Kraków 1910, s. 70.

5 Por. Sacra Congregatio Concilit, Decretum de sponsalibus et matrimonio iussu et auctoritate SS. D. N. Pii Papae X a S. Congregatione Concilii editum, Ne temere, n. 7, 02.08.1907, ASS 40 (1907), s. 529: „Imminente mortis periculo, ubi parochus, vel loci Ordinarius, vel sacerdos ab alterutro delegatus, haberi nequeat, ad consulendum conscientiae et (si casus ferat) legitimationi prolis, matrimonium contrahi valide ac licite potest - coram quolibet sacerdote et duobus testibus".

${ }^{6}$ Por. tamże, n. 7: „Si contingat ut in aliqua regione parochus locive Ordinarius, aut sacerdos ab eis delegatus, coram quo matrimonium celebrari queat, haberi non possit, eaque rerum conditio a mense iam perseveret, matrimonium valide ac licite iniri potest emisso a sponsis formali consensu coram duobus testibus". 
Pierwszy Kodeks Prawa Kanonicznego dla Kościoła łacińskiego, który zaczął obowiązywać od dnia 19 maja 1918 r. , nie przyniósł istotnej zmiany w dotychczas obowiązującym prawie regulującym zawieranie małżeństwa bez obecności świadka kwalifikowanego. Według normy zapisanej w kan. 1098, można było ważnie i godziwie zawrzeć małżeństwo jedynie wobec dwóch świadków w sytuacjach: 1) gdy istnieje niebezpieczeństwo śmierci, a nie ma proboszcza, ordynariusza lub kapłana delegowanego, lub nie można bez wielkiej trudności udać się do nich, żeby asystowali przy małżeństwie; 2) poza niebezpieczeństwem śmierci, jeśli roztropnie przewiduje się, że opisana wcześniej sytuacja będzie trwała przez miesiąc, to znaczy, że nie będzie świadka kwalifikowanego lub nie będzie można bez wielkiej trudności udać się do niego, żeby asystował przy małżeństwie. W obydwu sytuacjach, jeżeli był inny kapłan, powinien zostać wezwany ${ }^{8}$.

Dnia 25 stycznia 1983 r. Jan Paweł II konstytucją apostolską Sacrae disciplinae leges ogłosił kolejny Kodeks Prawa Kanonicznego dla Kościoła łacińskiego, który obowiązuje od 27 listopada 1983 r. ${ }^{9}$. Tak samo jak w Kodeksie Pio-Benedyktyńskim, tak i w nim, promulgowana została norma regulująca możliwość zawarcia małżeństwa w nadzwyczajnej formie (por. KPK 1983, kan. 1116). Nowością obecnie obowiązującego prawa jest zawarte w niej stwierdzenie, że „kto chce zawrzeć prawdziwe małżeństwo" (qui intendunt verum matrimonium inire), może je ważnie i godziwie zawrzeć pod pewnymi warunkami wobec samych świadków. Zmiana ta była następstwem paradoksalnych sytuacji zachodzących za czasów obowiązywania Kodeksu Pio-Benedyktyńskiego, którym należało zapobiegać. Osoby znajdują-

${ }^{7}$ Por. Benedictus XVI, Constitutio Apostolica Providentissima Mater Ecclesia, 27.05.1917; w: Codex Iuris Canonici Pii X Pontificis Maximi iussu digestus. Benedicti Papae XV auctoritate promulgatus. Praefatione, fontium annotatione et indice analytico-alphabetico ab E.mo Petro Card. Gasparri auctus, Romae 1936, s. XXXIX-XLII.

8 Por. KPK 1917, kan. 1098: „Si haberi vel adiri nequeat sine gravi incommodo parochus vel Ordinarius vel sacerdos delegatus qui matrimonio assistant ad normam canonum 1095, 1096: $1^{\circ}$ In mortis periculo validum et licitum est matrimonium contractum coram solis testibus; et etiam extra mortis periculum, dummodo prudenter praevideatur eam rerum conditionem esse per mensem duraturam; $2^{\circ}$ In utroque casu, si praesto sit alius sacerdos qui adesse possit, vocari et, una cum testibus, matrimonio assistere debet, salva coniugii validitate coram solis testibus".

9 Por. Ionnnes Paulus II, Constitutio Apostolica Sacrae disciplinae leges, 25.01.1983, AAS 75II (1983), s. VII.XIV; T. PAwLuk, Prawo kanoniczne wedtug kodeksu Jana Pawła II. Zagadnienia wstępne i normy ogólne, t. 1, Olsztyn 2002, s. 110. 
ce się obiektywnie w sytuacji opisanej w kan. 1098 KPK 1917, zawierały niejednokrotnie małżeństwa $\mathrm{w}$ formie cywilnej bez intencji zawarcia kanonicznego małżeństwa. Prowadziło to do szczególnych problemów, kiedy małżeństwo cywilne zostało uznane za nieważne na skutek nieprzestrzegania wymogów prawa cywilnego, zaś z drugiej strony było uznawane za ważnie zawarte przez Kościół, zgodnie z kan. 1098. Osoby były małżeństwem kanonicznym, mimo że zawarły je nieświadomie ${ }^{10}$.

Reszta zmian miała jedynie charakter redakcyjny. Była wynikiem rozszerzenia przez ustawodawcę w Kodeksie z 1983 r. grupy osób upoważnionych do asystowania przy zawarciu małżeństwa. Ponieważ nie tylko kapłani mogli błogosławić związki małżeńskie, ale i diakoni oraz świeccy (por. KPK 1983, kan. 1108, 1112), sformułowanie Kodeksu z 1917 r. - ,jeśli nie ma proboszcza, ordynariusza lub kapłana delegowanego, lub nie można bez poważnej niedogodności udać się do nich" ${ }^{11}$ - zostało zastąpione wyrażeniem: ,jeśli osoba, zgodnie $\mathrm{z}$ przepisem prawa kompetentna do asystowania jest nieosiągalna lub nie można do niej się udać bez poważnej niedogodności (...)"12.

Przy małżeństwach zawieranych w nadzwyczajnej formie, tak samo jak i w zwyczajnej, obecni powinni być przynajmniej dwaj świadkowie. Obydwa Kodeksy jednakże wprost tej liczb nie podają ${ }^{13}$. Ustawodawcy Kodeksów z 1917 r. i 1983 r. również nie przepisują żadnych szczegółowych warunków, jakie powinni spełniać świadkowie obecni przy zawarciu małżeństwa w nadzwyczajnej formie. Według komentatorów, muszą spełniać te same warunki co świadkowie zawarcia małżeństwa w ,zwykłych warunkach”.

Należy podkreślić, że poza drobnymi zmianami, kan. 1116 KPK 1983, w którym uregulowana jest nadzwyczajna forma zawarcia małżeństwa, jest ścisłą kopią kan. 1098 Kodeksu z 1917 r. Pozwala to, zgodnie kan. 6 § 2 KPK 1983, interpretować przepis w nim zapisa-

${ }^{10}$ Por. R. Navarro-Valls, The Form of the Celebration of Marriage, w: Á. MarzoA, J. Miras, R. Rodríguez-Ocaña (red.), Exegetical Commentary on the Code of Canon Law, English language ed. E. Caparros, P. Lagges, Vol. III/2, Montreal Chicago 2004, s. 1471.

${ }^{11}$ KPK 1917, kan. 1098: „Si haberi vel adiri nequeat sine gravi incommodo parochus vel Ordinarius vel sacerdos delegatus qui matrimonio assistant (...)”.

${ }^{12}$ KPK 1983, kan. $1116 \S 1$ : ,Si haberi vel adiri nequeat sine gravi incommodo assistens ad normam iuris competens (...)".

${ }^{13}$ Por. J. M. Serrano, De forma celebrationis matrimonii, w: P. V. Pinto (red.), Commento al Codice di Diritto Canonico, Libreria Editrice Vaticana 2001, s. 664. 
ny z uwzględnieniem dotychczasowej interpretacji starego prawa ${ }^{14}$. W związku z tym nie ma się czemu dziwić, że w analizie norm Kodeksu z 1983 r. znalazło się tak wiele uwag dotyczących „starego prawa”.

\section{Brak świadka kwalifikowanego według dokumentów Stolicy Apostolskiej i komentatorów Kodeksu z 1917 r.}

Początkowo przepisy kan. 1098 KPK 1917 interpretowano ściśle w duchu dekretu Ne temere - uważajac, że można normę w nim zawartą stosować jedynie w przypadku fizycznego braku świadka kwalifikowanego. Taka była oficjalna interpretacja. Dnia 10 marca 1928 r. została ona potwierdzona przez Papieską Komisję ds. Interpretacji Tekstów Prawnych. Komisja na przedstawione pytanie odpowiedziała, że w kanonie tym chodzi jedynie o fizyczną nieobecność proboszcza lub ordynariusza miejsca ${ }^{15}$. Za tego typu przeszkode uważano wówczas m.in. chorobę, złą drogę, śnieżycę, itp. Utrzymywano, że strach - np. przed karą cywilną - nie upoważnia do zawarcia małżeństwa wobec dwóch świadków, ponieważ zachodziła wtedy moralna, a nie fizyczna nieobecnośćc ${ }^{16}$.

Warto w tym miejscu przytoczyć również dwa wyroki Roty Rzymskiej z 1926 r. w sprawie o stwierdzenie nieważności małżeństwa. Mimo że uzasadnień w nich zawartych nie można było uznać za interpretację autentyczną, jednak pomagają one wyrobić sobie pogląd na temat interpretowania norm prawa kanonicznego przez prawników ówcześnie pracujących we wspomnianej dykasterii (por. kan. 17 § 3 KPK 1917). W pierwszym z wyroków Rota Rzymska uznała za nieważnie zawarte małżeństwo wobec samych świadków w sytuacji, kiedy kwalifikowany świadek był faktycznie osiągalny fizycznie i moralnie, zaś strony szczerze wierzyły, że w mieście nie ma biskupa, proboszcza ani kapłana, który mógłby być delegowany przez wcześniej wspomnianych do przyjęcia zgody małżeńskiej ${ }^{17}$. W kolejnym

${ }^{14}$ M. A. ŻurowsKI, Kanoniczne prawo matżeńskie Kościoła katolickiego, Katowice 1987, s. 322.

${ }^{15}$ Por. Pontificia Commissio ad Codicis Canones Authentice Interpretandos, Responsa ad proposita dubia, n. 1, 10.03.1928, AAS 20 (1928), s. 120.

${ }^{16}$ Por. H. A. Ayrinhac, Marriage Legislation in the New Code of Canon Law, New York, 1952, s. 263.

${ }^{17}$ Por. Rota Romana, Bona Fide Belief of Party That Neither Pastor Nor Ordinary Nor Delegate Can Be Reached, Is Non Sufficient, R.D. 18-17, 30.01.1926, w: 
wyroku Rota, orzekając nieważność małżeństwa, stwierdziła, że ponieważ kan. 1098 zawiera wyjątek od prawa, to powinien być on ściśle interpretowany, zgodnie z normą zapisaną w kan. 19. Zatem, zaistnienie warunków w nim opisanych musi być bezwzględnie udowodnione na forum zewnętrznym. W praktyce oznaczało to uznanie za nieważnie zawarte małżeństwo wobec dwóch świadków, gdy odległość do kapłana katolickiego, uprawnionego do błogosławienia związków małżeńskich, przekraczała 11 kilometrów, i dla stron nie stanowiło poważnej trudności pokonanie tej odległości ${ }^{18}$.

Wróćmy do przerwanego wątku. Dnia 25 lipca 1931 r. także w autentycznej interpretacji Papieska Komisja ds. Interpretacji Tekstów Prawnych uznała, że przez „nieobecność fizyczną” można rozumieć również przypadek, kiedy owi kwalifikowani świadkowie wprawdzie materialnie są obecni na miejscu, jednakże z powodu jakiejś poważnej przeszkody nie mogą asystować przy zawarciu małżeństwa ${ }^{19}$. Należy w tym miejscu odnotować, że jeśli przyjmie się, że interpretacja ta miała charakter deklaratywny, a nie rozszerzający, małżeństwa zawierane z powodu strachu świadka urzędowego, np. przed karą, przynajmniej po interpretacji dokonanej przez komisję $\mathrm{w}$ dniu 10 marca 1928 r. należy uznać za ważne ${ }^{20}$. Zdaniem Navarro-Vals, interpretacja autentyczna z 1931 r. zmieniała jednak znaczenie i zakres ustawy promulgowanej w kan. 1098 Kodeksu Pio-Benedyktyńskiego, zatem zgodnie z kan. 17 KPK 1917 przedstawione w niej rozumienie ustawy nie obowiązywało wstecznie ${ }^{21}$.

Dnia 24 kwietnia 1935 r. Kongregacja ds. Sakramentów w prywatnej odpowiedzi biskupowi Metz potwierdziła, że kodeksowa norma, w której ustawodawca reguluje nadzwyczajną formę zawarcia małżeństwa, obejmuje również przypadek, kiedy proboszcz lub ordynariusz nie mogą asystować przy zawarciu religijnego małżeństwa, gdy prawo cywilne zabrania im tego pod sankcją karną, tak że małżeństwo kościelne nie może być celebrowane przed kontraktem cywil-

T. L. Bouscaren (red.), Canon Law Digest. Officially Published Documents Affecting the Code of Canon Law 1933-1942, Vol. 2, Milwaukee 1956, s. 335.

${ }^{18}$ Por. Rota Romana, Exception to Be Strictly Interpreted. Distance of Eleven Kilometers from Pastor, Not Sufficient Per Se to Amount to Grave Inconvenience, R.D. 18-287, 29.07.1926, w: T. L. Bouscaren (red.), Canon Law Digest..., dz. cyt., s. 335-336.

${ }^{19}$ Por. Pontificia Commissio ad Codicis Canones Authentice Interpretandos, Responsa ad proposita dubia, n. 1, 25.07.1931, AAS 23 (1931), s. 388.

${ }^{20}$ Por. H. A. Ayrinhac, Marriage Legislation ..., dz. cyt., s. 264.

${ }^{21}$ Por. R. Navarro-Valls, The Form of the Celebration..., art. cyt., s. 1470. 
nym, a władze państwowe nie zezwalają na nie z powodu braku dokumentów wymaganych przez prawo cywilne ${ }^{22}$. Dziesięć lat później Papieska Komisja ds. Interpretacji Tekstów Prawnych w oficjalnej odpowiedzi potwierdziła, że wielka niedogodność, o której jest mowa w kan. 1098 KPK 1917, dotyczy nie tylko ordynariusza i delegowanego kapłana, ale również stron (a nawet jednej strony) pragnących zawrzeć małżeństwo ${ }^{23}$.

$\mathrm{Z}$ analizy przytoczonych wypowiedzi Papieskiej Komisji wynika zatem, że rozważana norma prawna obejmuje swoim zakresem nieobecność fizyczną i moralną świadka kwalifikowanego, a także sytuację, w której poważne niebezpieczeństwo grozi którejś ze stron. Interesujący przykład okoliczności upoważniających do zastosowania nadzwyczajnej formy małżeństwa dostarcza lektura pisma Delegata Apostolskiego w Stanach Zjednoczonych z 28 czerwca 1962 r. Zgodnie z nim, małżeństwo wobec dwóch świadków miała zawrzeć dziewczyna pełnoletnia $\mathrm{z}$ niepełnoletnim chłopakiem, którego rodzice nie chcieli wyrazić zgody na to małżeństwo, jeśli konsensus miałby być wyrażony w czasie katolickiej ceremonii. Mimo że biskup mógł zezwolić na małżeństwo kościelne bez skutków cywilnych, obawiał się jednak konsekwencji karnych ze strony rodziców chłopaka. Dziewczyna spodziewała się dziecka, zaś chłopak w niedługim czasie miał osiągnąć pełnoletniość. W zaistniałej sytuacji delegat zasugerował zawarcie małżeństwa wobec dwóch świadków ${ }^{24}$.

Według Żurowskiego, z dobrodziejstwa normy zapisanej w kan. 1098 KPK 1917 nie można było korzystać w sytuacji ograniczenia dostępu do własnego proboszcza, kiedy to jednak bez wielkiej trudności można było dostać się do jakiegokolwiek innego świadka kwalifikowanego upoważnionego do błogosławienia związków małżeńskich. Na stronach nie ciążył jednak obowiązek ponoszenia nieproporcjonalnych kosztów lub uciekania się do nadzwyczajnych środków, ażeby zadośćuczynić przepisom prawa, zawierając małżeństwo

${ }^{22}$ Por. Sacred Congregation of the Sacraments, Pastor Forbidden By Law to Assist at Marriage Because Civil Requisites Lacking, 24.04.1935, w: T. L. BousCAREN (red.), Canon Law Digest..., dz. cyt., s. 336.

${ }^{23}$ Por. Pontificia Commissio ad Codicis Canones Authentice Interpretandos, Responsa ad proposita dubia, n. 2, 03.05.1945, AAS 37 (1945), s. 149.

${ }^{24}$ Por. Apostolic Delegat in U.S., Extraordinary Form of Marriage Suggested in Difficult Case, 28.06.1961, w: T. L. Bouscaren, J. I. O’Connor (red.), Canon Law Digest. Officially Published Documents Affecting the Code of Canon Law 1958-1962, Vol. 5, Milwaukee 1963, s. 524. 
w zwykłej formie ${ }^{25}$. Biskupski komentując kan. 1098 Kodeksu Pio-Benedyktyńskiego, stwierdził, że dla aplikowania normy w nim zapisanej nie musiała już zachodzić, tak jak przewidywał dekret Ne temere, niemożliwość ogólna - wystarczała osobista w stosunku do nupturientów w konkretnych warunkach i okolicznościach ${ }^{26}$. Pogląd ten podzielał również Augustine. Jego zdaniem nie chodziło również o niemożliwość obejmującą regiony czy prowincje, lecz zwykłe przyczyny indywidualne, które pośrednio wywołane są przez lokalne warunki ${ }^{27}$.

W odróżnieniu od normy zawartej w punkcie 8 dekretu z $\mathrm{Ne}$ temere, kan. 1098 KPK 1917 nie zawierał żadnego określenia regionu, w którym niemożność zawarcia małżeństwa wobec świadka kwalifikowanego miała trwać przez miesiąc. Podążając za wywodem Bączkowicza, przedstawionym w podręczniku dla duchowieństwa, można odnieść wrażenie, że autor ten uznawał za wystarczającą trudność wezwania świadka urzędowego, która wynika z osobistego położenia nowożeńców, do zastosowania formy nadzwyczajnej jedynie w sytuacji niebezpieczeństwa śmierci. Sytuacja się zmieniała, gdy nie zachodziło niebezpieczeństwo śmierci. Wtedy też niemożliwość musiała dotyczyć ogółu osób ${ }^{28}$. Jeśli chodzi o sytuację, w której nie ma niebezpieczeństwa śmierci, Ayrinhac uważał, że nieobecność musi być moralnie pewna w szerokim sensie. Musi być nabyta przez rozeznanie lub z informacji publicznych albo faktów notorycznych. Zwykła nieobecność nie jest wystarczająca. Jeśli strony mogą napisać do proboszcza i on może bez poważnych trudności przybyć $\mathrm{w}$ przeciągu miesiąca, $\mathrm{z}$ małżeństwem należało poczekać ${ }^{29}$.

Jak zauważa Sztafrowski, małżeństwo jest nieważnie zawarte, jeśli wprawdzie jest nieosiągalny własny proboszcz, ale można udać się do innego, by na własnym terytorium asystował przy zawarciu małżeństwa $^{30}$. Małżeństwo zawarte wobec samych tylko świadków jest waż-

${ }^{25}$ Por. M. A. Żurowski, Kanoniczne prawo matżeńskie okresu posoborowego, Katowice 1976, s. 334.

${ }^{26}$ Por. S. BiskuPSKi, Prawo matżeńskie Kościoła rzymskokatolickiego, t. 1, Warszawa 1956, s. 351.

${ }^{27}$ Por. P. Ch. Augustine, A commentary on the New Code of Canon Law. Book 3, Vol. V, London 1919, s. 294.

${ }^{28}$ Por. F. BĄczkowicz, Prawo kanoniczne. Podręcznik dla duchowieństwa, t. 2, Opole 1958, s. 294-295.

${ }^{29}$ Por. H. A. Ayrinhac, Marriage Legislation..., dz. cyt., s. 265.

${ }^{30}$ Por. E. SzTafrowski, Prawo kanoniczne w okresie odnowy soborowej. Podrecznik dla duchowieństwa, t. 2, Warszawa 1979, s. 294. 
ne również wtedy, gdy nowożeńcy umyślnie przenieśli się do miejscowości, w której wspomniane trudności zachodzą lub w tymże celu ślub odłożyli (in fraudem legis) ${ }^{31}$.

\section{Brak świadka kwalifikowanego według komentatorów Kodeksu z 1983 r.}

Według opinii Navarro-Valls, nie można uznać za moralną niemożliwość wezwania świadka urzędowego w sytuacji, kiedy ten nie może być obecny przy wyrażeniu zgody ze względu na wyraźną normę zapisaną w kan. $1085 \S 2$ KPK 1983. Oznacza to, że jeśli któreś z nupturientów zawarło wcześniej nieważne małżeństwo albo zostało ono rozwiązane $z$ jakiejkolwiek przyczyny, osoba ta nie może zawrzeć w nadzwyczajnej formie małżeństwa dopóki zgodnie z prawem i w sposób pewny nie stwierdzi się nieważności lub rozwiązania pierwszego małżeństwa. Ponadto, jak zauważa autor, niemożliwość osiągnięcia urzędowego świadka musi być obiektywna i indywidualna. Obiektywna jest wtedy, gdy świadek urzędowy jest nieosiągalny na skutek rzeczywistych okoliczności, a nie fałszywych subiektywnych szacunków, gdyż inaczej zawartego małżeństwa nie można uznać za ważne. Jeśli chodzi o indywidualną, to dotyka ona pary, bez względu na okoliczności, które istnieją w miejscu lub dotyczą innych osób $^{32}$. Beal niemożliwość ,indywidualną” określił terminem „relatywna", jako przykład podając sytuację, kiedy podróż dwadzieścia pięć mil może być tylko małą niedogodnością dla osoby mającej do dyspozycji dobre drogi i samochód, zaś wielką niedogodnością dla tych, którzy muszą podróżować pieszo ${ }^{33}$.

Huels jako przykład - fałszywych subiektywnych szacunków dotyczących niemożności osiągnięcia uprawnionego do asystowania przy zawarciu małżeństwa - podaje sytuację, w której katolik (mężczyzna), zobowiązany przez prawo cywilne do uzyskania zgody na zawarcie małżeństwa, przekonany jest, że działanie takie jest wtargnięciem rządu w celebrację sakramentu małżeństwa. Sumienie podpowiada mu, że zwrócenie się do władzy państwowej o zgodę przed zawarciem

${ }^{31}$ F. BączKowicz, Prawo kanoniczne..., dz. cyt., s. 295.

${ }^{32}$ Por. R. Navarro-Valls, The Form of the Celebration ..., art. cyt., s. 1471-1472.

${ }^{33}$ Por. J. P. Beal, The Extraordinary Canonical Form, w: J. P. Beal, J. A. Coriden, T. J. Green (red.), New Commentary on the Code of Canon Law, New York 2000, s. 1334. 
małżeństwa byłoby przyznaniem jej jurysdykcji nad sakramentem. Mimo usilnych starań mężczyzna nie jest w stanie porzucić swoich poglądów. Usiłuje nawet przekonać kilku duchownych, by asystowali przy zawarciu przez niego małżeństwa bez wymaganej zgody, jednakże wszyscy odmówili. Huels twierdzi, że niemożność w tym przypadku jest jedynie wynikiem własnych poglądów mężczyzny. Łatwo mógłby osiągnąć świadka urzędowego, jednakże stawiając niegodziwe warunki, domaga się od niego przeciwstawienia się słusznemu prawu państwowemu. Zgodnie z powszechnym przekonaniem, wymóg uzyskania wspomnianej zgody państwowej nie jest niegodziwy. Kapłan lub diakon odmawiając asystowania, postępuje godziwie i właściwie. Sytuacja ta, zdaniem autora, ma odzwierciedlenie w kan. $1071 \S 1,2^{\circ} \mathrm{KPK} 1983$, zgodnie z którym ,poza wypadkiem konieczności, nie można bez zezwolenia ordynariusza miejsca asystować przy małżeństwie, które nie może być uznane lub zawarte według prawa państwowego" "34. Na poparcie niniejszego poglądu warto zauważyć, że Beal, analizując kan. 1116 KPK 1983 jako przykład poważnej niedogodności, podał niemożliwość moralną będącą wynikiem niesprawiedliwego prawa cywilnego ${ }^{35}$.

Inny przykład subiektywnej oceny niemożności osiągnięcia uprawnionego kapłana lub diakona podał Woestman. Według niego, nie uprawnia do zawarcia małżeństwa w nadzwyczajnej formie przekonanie katolika, że duchowni katoliccy posługujący w okolicy są zbyt mało „ortodoksyjni” w stosunku do lefebrystów, na skutek czego osoba zobligowana do zawarcia małżeństwa w formie kanonicznej wyraża zgodę małżeńską w obecności kapłana schizmatyckiego ${ }^{36}$.

Provost zajął się również analizą możliwości zawarcia małżeństwa bez obecności świadka urzędowego w kontekście prawa promulgowanego przez biskupa diecezjalnego. Czasami ustawodawca partykularny nakazuje odczekać nupturientom określony czas - od zgłoszenia woli zawarcia małżeństwa kompetentnemu duszpasterzowi do ślubu - aby okres ten poświęcić na właściwe przygotowanie do mał-

${ }^{34}$ Por. J. M. Huels, Canon 1116: Extraordinary Form of Marriage in Conflict with Civil Law, w: S. A. Euart, J. Alesandro, P. B. R. Hartmann (red.), Roman Replies and CLSA Advisory Opinions 2010, Washington 2010, s. 149-150.

${ }^{35}$ Por. J. P. Beal, The Extraordinary Canonical Form, art. cyt., s. 1334.

${ }^{36}$ Por. W. H. Woestman, Canons 144, 1108, 1116: Validity of a Marriage Celebrated by a Priest Not in Ecclesial Communion, w: F. S. Pedone, J. I. Donlon (red.), Roman Replies and CLSA Advisory Opinions 2003, Washington 2003, s. 45-47. 
żeństwa. Autor w obszernym wyjaśnieniu obala argumenty zwolenników możliwości zastosowania w opisanych okolicznościach nadzwyczajnej formy. Zdaniem kanonisty, przywołane prawo partykularne jest wynikiem dbałości biskupów diecezjalnych o należyte przygotowanie nupturientów do małżeństwa. Nie można go traktować jedynie automatycznie i mechanicznie, jako czasowego zakazu zawierania małżeństw, o czym w kan. 1077 § 1 KPK 1983, gdyż byłoby to wykroczeniem przeciwko wypełnianiu pasterskich funkcji proboszczów $^{37}$. Podobny pogląd reprezentuje Beal ${ }^{38}$.

Golden zapytany, jak może zawrzeć małżeństwo mężczyzna, emigrant - o nieuregulowanym statusie w kraju pobytu, gdzie duchowny asystujący przy zawarciu małżeństwa musi się upewnić pod groźbą odpowiedzialności karnej, czy nupturienci uzyskali zgodę państwową na zawarcie małżeństwa - stwierdza, że najlepszym rozwiązaniem w jego sytuacji jest zawarcie małżeństwa jedynie w obecności dwóch świadków zwykłych. Ponadto autor wyraża opinię, że przy wyrażeniu zgody małżeńskiej w tej sytuacji nie powinien być obecny duchowny, mimo że kodeks sugeruje co innego ${ }^{39}$. W tym miejscu należy podkreślić, że wśród kanonistów nie ma jednakowej opinii, czy emeryci mogą zawrzeć małżeństwo jedynie w obecności dwóch świadków, jeśli prawo państwowe wymaga uprzednio uzyskania przez nich stosownej zgody pod odpowiedzialnością karną, zaś z drugiej strony, zawarcie małżeństwa $\mathrm{w}$ formie publicznej spowoduje znaczące pogorszenie ich warunków materialnych ${ }^{40}$.

\section{Niebezpieczeństwo śmierci}

Jak już wcześniej zostało zasygnalizowane, ustawodawca w kan. 1098 KPK 1917 dopuścił możliwość zawarcia ważnego małżeństwa wobec dwóch świadków, jeśli zachodzi niebezpieczeństwo śmierci i nie ma proboszcza, ordynariusza lub kapłana delegowanego, albo nie można bez wielkiej trudności udać się do nich, żeby asystowali przy małżeństwie.

${ }^{37}$ Por. J. H. Provost, Canons 1077 and 1116: The Right to Marry and Diocesan Policies Requiring Minimal Time of Preparation, w: W. A. Schumacher, J. J. Cuneo (red.), Roman Replies and CLSA Advisory Opinions 2003, Washington 1986, s. 343-346.

${ }^{38}$ Por. J. P. BEAL, The Extraordinary Canonical Form, art. cyt., s. 1334.

${ }^{39}$ Por. P. L. Golden, Canon 1116: Marriage of an Undocumented Immigrant, w: F. S. Pedone, J. I. Donlon (red.), Roman Replies..., dz. cyt., s. 76-78.

${ }^{40}$ Por. J. M. Huels, Canon 1116..., art. cyt., s. 102-101. 
Niebezpieczeństwo śmierci (periculo mortis) to stan, w którym istnieje uzasadniona możliwość, że śmierć w najbliższym czasie nastąpi, chociaż nie jest to zupełnie pewne. Odróżnić trzeba niebezpieczeństwo śmierci od agonii (articulo mortis), gdy śmierć jest prawie pewna. Jako przyczyny powodujące wspomniane zagrożenie przed 1983 r. wymieniano między innymi: chorobę, wypadek samochodowy, poważną awarię w czasie podróży lotniczej lub morskiej, powódź, trzęsienie ziemi, bombardowanie, udział w akcji frontowej ${ }^{41}$. Biskupski, mówiąc o chorobie, która może upoważnić do zawarcia małżeństwa wobec dwóch świadków, stwierdza, że to lekarze oceniają, czy jest ona niebezpieczna dla życia pacjenta ${ }^{42}$. Bączkowicz dodaje ponadto: wyrok śmierci ${ }^{43}$.

Po sprecyzowaniu terminów, wróćmy do przerwanego wątku. Ustawodawca w Kodeksie z 1917 r. nie wspominał, jak był to uczynił promulgując dekret Ne temere, p. 7, że niebezpieczeństwo śmierci ma być bezpośrednie, bliskie (imminente mortis periculo). Zatem, mogło być ono prawdopodobne lub możliwe ${ }^{44}$. Aby zawrzeć małżeństwo wobec dwóch świadków, przy zaistnieniu warunków, o których mowa w kan. 1098 KPK 1917, wystarczyło, że jedna osoba znalazła się $\mathrm{w}$ rzeczywistym niebezpieczeństwie śmierci. Motywy zawarcia małżeństwa, w odróżnieniu od regulacji promulgowanej w dekrecie Ne temere, nie były istotne. Małżeństwo w niebezpieczeństwie śmierci można było zawrzeć również z innych powodów niż uspokojenie sumienia i uprawnienie potomstwa. Szafrański zwraca uwagę, że pobudka powinna być słuszna. Wydaje się to oczywiste ze względu na powagę i znaczenie małżeństwa ${ }^{45}$.

Nagłe i niespodziewane ustanie czynnika powodującego niebezpieczeństwo śmierci strony lub stron nie wpływa na ważność małżeństwa $^{46}$. Pomyłka co do zaistnienia niebezpieczeństwa śmierci także nie skutkuje nieważnością ${ }^{47}$.

${ }^{41}$ Por. M. A. Żurowski, Kanoniczne prawo matżeńskie okresu..., dz. cyt., s. 337.

${ }^{42}$ Por. S. Biskupski, Prawo matzeńskie..., dz. cyt., s. 353.

${ }^{43}$ Por. F. Bączkowicz, Prawo kanoniczne..., dz. cyt., s. 293.

${ }^{44}$ Por. P. Ch. Augustine, A commentary..., dz. cyt., s. 295.

${ }^{45}$ Por. W. SzAFrańsKi, Rzymskokatolickie prawo matżeńskie po Drugim Soborze Watykańskim, Lublin 1971, s. 236.

${ }^{46}$ Por. M. A. ŻUrowski, Kanoniczne prawo małżeńskie okresu... , dz. cyt., s. 337-338.

${ }^{47}$ Por. F. BączKowicz, Prawo kanoniczne..., dz. cyt., s. 293. 
Jak zauważa Żurowski, jest rzeczą oczywistą, że jeżeli w tych warunkach proboszcz, czy kapłan przez niego delegowany jest osiągalny lub może przybyć, należy go wtedy wezwać ${ }^{48}$.

Ponieważ, jak to wcześniej zostało przedstawione, kan. 1116 KPK 1983 jest ścisłą kopią kan. 1098 Kodeksu z 1917 r. (z wyjątkiem drobnych zmian), normę w nim zapisaną interpretujemy $\mathrm{z}$ uwzględnieniem interpretacji prawa obowiązującego przed promulgacją Kodeksu z 1983 r. (por. 6 § 2 KPK 1983).

\section{Poza niebezpieczeństwem śmierci}

Dnia 10 listopada 1925 r. Papieska Komisja potwierdziła w autentycznej interpretacji, że do ważnego i godziwego zawarcia małżeństwa wobec dwóch świadków poza niebezpieczeństwem śmierci, nie wystarcza jedynie brak kwalifikowanego świadka, lecz konieczne jest także istnienie moralnej pewności, opartej na powszechnej wiedzy lub dochodzeniu, że przez miesiąc nie będzie on ani obecny, ani przystępny bez poważnej niedogodności ${ }^{49}$. Osoby, które dołożyły należytego starania, by rozeznać, czy uprawniony szafarz będzie nieosiągalny przez miesiąc, i zdecydowały się na zawarcie małżeństwa w nadzwyczajnej formie, roztropnie przewidując, że zaistniały okoliczności zezwalające na to, zawierają małżeństwo ważnie, mimo że niespodziewanie wcześniej po zawarciu małżeństwa stan się zmieni. Zdaniem Żurowskiego, analogicznie rzecz się ma z zagrożeniem dla świadków urzędowych oraz stron - skutkującym niemożliwością zawarcia małżeństwa w zwykłej formie. Jeśli według roztropnego przewidywania stan taki będzie miał miejsce co najmniej miesiąc, narzeczeni będą mogli zawrzeć małżeństwo w nadzwyczajnej formie. Małżeństwo będzie ważne i godziwe, nawet gdyby okazało się później, że krótko po jego zawarciu niespodziewanie zagrożenie ustało.

Mimo że okres jednego miesiąca należało liczyć zgodnie z normą zawartą w kan. 32 § 2 Kodeksu Pio-Benedyktyńskiego, czyli traktować jako 30 dni, to jednak nie można liczyć go zbyt matematycznie, ponieważ zgodnie z interpretacją autentyczną chodzi o przewidywanie $\mathrm{z}$ moralną pewnością ${ }^{50}$. Stąd, jeśli świadek kwalifikowany przy-

\footnotetext{
${ }^{48}$ M. A. ŻUrowski, Kanoniczne prawo matżeńskie okresu..., dz. cyt., s. 338.

${ }^{49}$ Por. Pontificia Commissio ad Codicis Canones Authentice Interpretandos, Responsa ad proposita dubia, n. 8, 10.11.1925, AAS 17 (1925), s. 583.

${ }^{50}$ Por. M. A. Żurowski, Kanoniczne prawo małżńskie okresu... , dz. cyt., s. 333-334.
} 
będzie np. za trzy tygodnie, nupturienci powinni poczekać na niego ${ }^{51}$. Czas należy liczyć od momentu, kiedy wszystko jest gotowe do ślu$\mathrm{bu}^{52}$. Okres ten musi być pełny i ciągły ${ }^{53}$.

Norma zawarta w kan. 1098 KPK 1917 uległa zmianie w stosunku do analogicznej, ogłoszonej w dekrecie Ne temere, która nakazywała poczekać nupturientom miesiąc - zanim skorzystają z nadzwyczajnej formy. Ustawodawca w Kodeksie Pio-Benedyktyńskim mówił jedynie o roztropnym przewidywaniu, że sytuacja będzie trwała miesiąc. Prawodawca nie określił, od którego momentu należy liczyć czas. Czy od dnia, kiedy wszystko jest gotowe do zawarcia małżeństwa, czy też od momentu decyzji nupturientów o zawarciu małżeństwa. Przyjmuje się, że czas zaczyna biec od chwili, kiedy wszystko jest już gotowe do zawarcia małżeństwa ${ }^{54}$. Aktualnie obowiązujące przepisy regulujące omawianą w niniejszym podrozdziale materię interpretujemy w duchu starego prawa (por. $6 \S 2$ KPK 1983).

\section{Użycie środków komunikacyjnych a stosowanie nadzwyczajnej formy małżeństwa}

Wraz z rozwojem techniki i dostępu do niej, wśród kanonistów zmieniały się opinie na temat konieczności użycia telefonu i telegrafu (jeśli to możliwe) w celu skontaktowania się z kompetentnym szafarzem mogącym asystować przy zawarciu małżeństwa, zanim strony wyrażą zgodę wobec samych świadków. Ayrinhac w 1952 r. uważał, że posłużenie się telefonem lub telegramem nie było konieczne, by skomunikować się z proboszczem ${ }^{55}$. Augustine stwierdzał w 1919 r., że telefon i telegram nie są zwykłymi środkami komunikacji; często nie są bezpieczne i mogą być nadużyte dla rozgłosu ${ }^{56}$. Biskupski w 1956 r. wyraził pogląd, że strony pragnące zawrzeć małżeństwo powinny również skontaktować się z kompetentnym kapłanem za pomocą środków niezwykłych, np. telefonicznie, telegraficznie, przez radio. Jeśli byłoby niemożliwe wezwanie kompetentnego świadka urzędo-

\footnotetext{
${ }^{51}$ Por. H. A. Ayrinhac, Marriage Legislation ..., dz. cyt., s. 265.

${ }^{52}$ Por. F. BączKowicz, Prawo kanoniczne ... dz. cyt., s. 295.

${ }^{53}$ Por. W. Góralski, Kościelne prawo matżeńskie, Warszawa 2006, s. 247.

${ }^{54}$ Por. S. Woywod, C. Smith, A practical commentary on the code of Canon Law, Vol. I, New York - London 1943, s. 686.

${ }^{55}$ Por. H. A. Ayrinhac, Marriage Legislation..., dz. cyt., s. 264.

${ }^{56}$ Por. P. Ch. Augustine, A commentary..., dz. cyt., s. 295.
} 
wego także przy pomocy tych środków, wtedy dopiero można mówić o niemożności fizycznej. Podążając za wywodem kanonisty, można dojść do przekonania, że osoby nie miały obowiązku z tych środków korzystać, jeśli wiązałoby się to z wielkimi trudnościami, np. grzywną, więzieniem, czyli niemożliwością moralną ${ }^{57}$. Bączkowicz nie domagał się użycia nadzwyczajnych środków ${ }^{58}$.

Warto w tym miejscu mieć na względzie pismo Sekretariatu Stanu z 5 stycznia 1892 r. do ordynariuszy w Germanii, według którego użycie telegramu w sprawie prośby do Stolicy Apostolskiej o jurysdykcję bądź delegację - było zabronione ${ }^{59}$. Niemały wpływ na opinie kanonistów wywarła również odpowiedź udzielona 12 listopada 1922 r. przez Papieską Komisję ds. Interpretacji Tekstów Prawnych. Zgodnie z nią, przez niemożliwość odniesienia się do ordynariusza miejsca, o której w kan. 1044 i 1045 § 3 KPK 1917, należało rozumieć sytuację, w której możliwość kontaktu $\mathrm{z}$ nim jest jedynie przez telegram, bądź telefon ${ }^{60}$.

Interpretacja z 1922 r. stała się źródłem normy zawartej w § 4 kan. 1079 KPK 1983 ${ }^{61}$. Zgodnie z decyzją ustawodawcy w nim zapisaną, przez niemożliwość odniesienia się w niebezpieczeństwie śmierci do miejscowego ordynariusza - o udzielenie dyspensy od zachowania formy obowiązującej przy zawarciu małżeństwa, jak i od wszystkich i poszczególnych przeszkód z prawa kościelnego, czy to publicznych, czy tajnych, z wyjątkiem przeszkody wypływającej ze święceń prezbiteratu - rozumie się sytuację, gdy można to uczynić tylko przy pomocy telegrafu lub telefonu (por. KPK 1983, kan. 1079 § 2-4). Z powyższego nasuwa się wniosek, że również obecnie - to jest za obowiązywania przepisów Kodeksu z 1983 r. - zwyczajnym środkiem komunikacji przy zwracaniu się do ordynariusza o dyspensę nie jest telefon ani telegram. Podobnie, zdaniem Góralskiego, jest przy załatwianiu spraw na drodze administracyjnej z kurią biskupią ${ }^{62}$ oraz, według Krukow-

${ }^{57}$ Por. S. Biskupski, Prawo matżeńskie..., dz. cyt., s. 353.

${ }^{58}$ Por. F. BączKowicz, Prawo kanoniczne..., dz. cyt., s. 294.

${ }^{59}$ Por. Secretaria Status, Gratiae seu dispensationes non defcent impetrari a Sede apostolica per telegraphum, sed in scriptis, 05.01.1982, ASS 24 (1891-1892), s. 447.

${ }^{60}$ Por. Pontificia Commissio ad Codicis Canones Authentice Interpretandos, Responsa ad proposita dubia, n. 5, 12.11.1922, AAS 14 (1922), s. 662.

${ }^{61}$ Por. J. Fornés, Diriment Impediments in General, w: Á. MarzoA, J. Miras, R. Rodríguez-Ocaña (red.), Exegetical Commentary..., Vol. III/2, dz. cyt., s. 1164.

${ }^{62}$ Por. W. Góralski, Matżeństwo, w: J. Krukowski (red.), Komentarz do Kodeksu Prawa Kanonicznego. Księga IV. Uświęcające zadanie Kościoła, t. III.2, Poznań 2011, s. 278. 
skiego, przy zwracaniu się do Stolicy Apostolskiej o łaskę dyspensy ${ }^{63}$. Według Baura, telefon i telegram są uznawane za środki nadzwyczajne nie ze względu na trudność ich użycia, lecz z powodu braku bezpieczeństwa w sytuacji ochrony właściwego odniesienia do kompetentnej władzy ${ }^{64}$.

Biorąc pod uwagę istnienie w aktualnym prawodawstwie Kościoła łacińskiego normy, zgodnie z którą: przez niemożność odniesienia się do miejscowego ordynariusza, w wypadku, o którym w kan. 1079 $\S 2$, rozumie się sytuację, gdy można to uczynić tylko przy pomocy telegrafu lub telefonu (por. kan. $1079 \S 4$ KPK 1983) oraz fakt, że $\mathrm{z}$ istnienia analogicznej normy we wcześniej istniejącym ustawodawstwie Kościoła łacińskiego kanoniści wysnuwali wniosek, że użycie telefonu i telegramu nie jest konieczne do wezwania kompetentnego duchownego do asystowania przy zawarciu małżeństwa, aby móc wypowiedzieć ważnie zgodę małżeńską jedynie w obecności dwóch świadków, nasuwa się pytanie, czy również dzisiaj, przez niemożliwość skontaktowania się z kompetentnym do asystowania świadkiem urzędowym w okolicznościach opisanych w kan. 1116 KPK 1983 należy rozumieć niemożliwość zastosowania innych środków komunikacji niż telefon i telegram? Niestety na tak postawione pytanie nasuwają się różne odpowiedzi.

Biorąc pod uwagę cel ustawy zapisanej w kan. 1044 i $1045 \S 3$ KPK 1917 oraz 1079 KPK 1983 - to jest: potrzeba zapewnienia dyskrecji przy ubieganiu się o łaskę dyspensy oraz wymóg zwracania się o dyspensę za pomocą zwykłego pisma, aby można było udowodnić fakt jej udzielenia pro foro externo - wydaje się uzasadniony pogląd, zgodnie z którym nie ma obowiązku kontaktowania się z uprawnioną osobą do asystowania przy zawarciu małżeństwa za pomocą środków nadzwyczajnych jedynie wtedy, kiedy ich użycie wiązałoby się z wielkimi trudnościami dla którejkolwiek ze stron, świadka urzędowego czy też świadka zwykłego ${ }^{65}$. Z drugiej zaś strony, ponieważ w kan. 1079-1080 KPK 1983 nie ma wprost zapisanego stwierdzenia,

${ }^{63}$ Por. J. Krukowski, Konkretne akty administracyjne, w: J. Krukowski (red.), Komentarz do Kodeksu Prawa Kanonicznego, t. 1, Poznań 2003, s. 154.

${ }^{64}$ Por. E. Baura, Dispensations, w: Á. Marzoa, J. Miras, R. Rodríguez-OcaÑA (red.), Exegetical Commentary on the Code of Canon Law, English language ed. E. Caparros, P. Lagges, Vol. I, Montreal Chicago 2004, s. 660.

${ }^{65}$ Por. KPK 1917, kan. 18; KPK 1983, kan. 17, S. BiskuPSKi, Prawo matżeńskie..., dz. cyt., s. 120. 353; E. BAura, Dispensations, art. cyt., s. 660. 
że ustawodawca, promulgując powyższe normy, kieruje się oprócz dobra duchowego stron, potrzebą zachowania dyskrecji przy ubieganiu się o dyspensę, a także uwzględniając różne - często rozbieżne opinie kanonistów na temat potrzeby zastosowania środków nadzwyczajnych w okolicznościach, o których kan. 1098 KPK 1917 - należy stwierdzić, że pomimo podjętych zabiegów interpretacyjnych trudno usunąć wątpliwości interpretacyjne kan. 1116 KPK 1983. Oznaczałoby to, że zgodnie z kan. 14 KPK 1983 - według którego, kiedy istnieje wątpliwość prawna ustawa nie obowiązuje, nawet unieważniająca i uniezdalniająca - dopóki wątpliwość nie zostanie usunięta przez prawodawcę, można przyjąć za obowiązującą najbardziej „łagodną” opinię interpretacyjną kan. 1098 KPK 1917 i uznać, że w okolicznościach opisanych w kan. 1116 KPK 1983 nie ma obowiązku stosowania kiedykolwiek środków nadzwyczajnych, aby za ich pomocą wezwać świadka urzędowego ${ }^{66}$.

Jeśli chodzi o tekst wysłany przy użyciu fax'u, sms'a i mail'a, ponieważ urządzenia te działają na zasadach analogicznych do sposobu działania telefonu i telegramu, również je należałoby uznać za nadzwyczajne środki komunikacji. Zwyczajnym środkiem komunikacji jest pismo wysłane za pomocą publicznego operatora pocztowego, bądź też dostarczone osobiście ${ }^{67}$.

\section{Nadzwyczajna forma zawarcia małżeństwa u niekatolików}

Na marginesie rozważań warto zastanowić się, jak należy traktować związek małżeński niekatolików, którzy będąc zobligowani do zawierania małżeństw zgodnie z dyscypliną własnego Kościoła lub wspólnoty wyznaniowej, do której przynależą, wyrazili zgodę małżeńską bez zachowania przepisanej przez własne prawo formy, w warunkach usprawiedliwiających katolików do zawarcia małżeństwa w formie nadzwyczajnej. Pomocne w rozwiązaniu tej trudności mogą okazać się opracowania, jakie współcześni autorzy poświęcili ważności związków zawartych przez wiernych przynależących do Kościoła akatolickiego wschodniego bez zachowania rytu świętego. Wierni ci muszą bowiem zgodnie z prawem, któremu podlegają, zawierać mał-

${ }^{66}$ Por. R. Sobański, Normy ogólne, w: J. KRUKowsKi (red.), Komentarz do Kodeksu Prawa Kanonicznego, dz. cyt., t. 1, s. 65.

${ }^{67}$ Por. E. BAura, Dispensations, art. cyt., s. 660. 
żeństwo z zachowaniem świętego obrzędu. Błogosławieństwo kapłana jest wymagane do ważności zawartego przez nich małżeństwa.

Autorzy zauważają, że jeśli strony celowo pominęły zachowanie rytu świętego, który bez przeszkód mogliby przyjąć, wtedy małżeństwo prawosławnych uznawane jest na forum Kościoła katolickiego, jako nieważne. Sytuacja diametralnie się zmienia, kiedy zawierają małżeństwo bez błogosławieństwa kapłańskiego, w okolicznościach usprawiedliwiających stosowanie formy nadzwyczajnej (in gravi incommodo). Wówczas mimo odmiennego podejścia dyscypliny prawosławnej do takich związków, Kościół katolicki uznaje, że małżeństwa te cieszą się przychylnością prawa, stwierdzając, że kompetentnym do orzeczenia ich nieważności jest trybunał Kościoła katolickiego, a nie, jak w pierwszym przypadku, ordynariusz lub proboszcz po konsultacji $\mathrm{z}$ ordynariuszem (upoważnieni do rozpoznania stanu wolnego).

Racją usprawiedliwiającą do ważnego zawarcia małżeństwa w formie nadzwyczajnej przez prawosławnych, mimo jej braku w dyscyplinie Kościoła prawosławnego, jest opinia, że prawo naturalne do zawarcia małżeństwa przeważa nad prawem ludzkim ${ }^{68}$. Inny autor dodaje, że skoro osoby te nie są zobligowane do zachowania dyscypliny Kościoła katolickiego, nie obowiązuje ich przepis, według którego małżeństwa $\mathrm{w}$ formie nadzwyczajnej powinny być zawierane w obecności dwóch świadków ${ }^{69}$.

\section{Zakończenie}

Normy prawa regulujące możliwość zawarcia małżeństwa jedynie wobec świadków wydają się opierać na doświadczeniu życiowym. Obejmują niemal wszystkie sytuacje, w których mogą się znaleźć wierni, którzy chcą zawrzeć związek małżeński mimo niemożliwości uczynienia tego w sposób zwyczajnie przepisany prawem ${ }^{70}$. Źródłem istnienia tych norm jest prawo naturalne osoby do zawarcia małżeństwa.

${ }^{68}$ Por. U. Nowicka, Stwierdzenie stanu wolnego wiernych prawosławnych na forum Kościoła katolickiego, Warszawa 2012, s. 339-351.

${ }^{69}$ Por. P. N. ScHöch, Canon 1116 and CCEO Canon 832 1: The Application of the Extraordinary Form of Marriage to Unions Celebrated Between Orthodox Parties Celebrated without Priestly Blessing, w: F. S. Pedone, J. I. Donlon (red.), Roman Replies..., dz. cyt., s. 72-78.

${ }^{70}$ Por. M. A. Żurowski, Kanoniczne prawo matżeńskie okresu..., dz. cyt., s. 231. 
Nieznajomość przepisu zamieszczonego w kan. 1116 KPK 1983 bądź jego niewłaściwa interpretacja może stać się przyczyną błędnego rozeznania stanu kanonicznego osób po rozwodzie, pragnących ponownie zawrzeć małżeństwo. Zwłaszcza problematyczna wydaje się kwestia, kiedy pochodzą one $\mathrm{z}$ krajów, gdzie duchownych katolickich było niewielu bądź panował w nich reżim utrudniający praktykowanie wiary katolickiej. W związku z tym wydaje się konieczne przybliżenie czytelnikowi normy dotyczącej nadzwyczajnej formy zawarcia związku małżeńskiego.

Odwołanie się do wcześniej obowiązujących przepisów regulujących omawianą materię pozwala lepiej uchwycić zamysł prawodawcy (por. KPK 1983, kan. 17, 19). Odniesienie to jest uzasadnione, ponieważ, poza drobnymi zmianami kan. 1116 KPK 1983, stanowi w dużej mierze kopię kan. 1098 Kodeksu z 1917 r. Umożliwia to, zgodnie kan. 6 § 2 KPK 1983, interpretować normy w nim zapisane w duchu dotychczasowej interpretacji „starego prawa" "71. Należy również odnotować fakt, że normy KPK 1917 o nadzwyczajnej formie zawarcia małżeństwa stanowią także poprawioną wersję, i to niezbyt zmienioną, przepisów dekretu Ne temere (p. 7-8).

Mimo że w obrządku wschodnim błogosławieństwo kapłana jest elementem istotnym i konstytutywnym zawartego w zwykłych warunkach małżeństwa, Kodeks Kanonów Kościołów Wschodnich zawiera jednak normę analogiczną do tej z kan. 1116 Kodeksu Kościoła łacińskiego z 1983 r. ${ }^{72}$. Nowością w stosunku do Kodeksu z 1983 r. jest zapisane w niej zlecenie (wpływające jedynie na godziwość) zwrócenia się z prośbą do innego kapłana (nawet akatolickiego), gdyby był obecny i byłoby to możliwe, aby pobłogosławił małżeństwo zawierane tylko wobec zwykłych świadków. W tych okolicznościach wszyscy kapłani - z wyjątkiem akatolickich - mają przyznaną władzę dyspensowania,

${ }^{71}$ M. A. Żurowski, Kanoniczne prawo matżeńskie Kościoła..., dz. cyt., s. 322.

${ }^{72} \mathrm{KKKW}$, kan. $832 \S 1$ : „Si haberi vel adiri non potest sine gravi incommodo sacerdos ad normam iuris competens, celebrare intendentes verum matrimonium illud valide ac licite coram solis testibus celebrare possunt: $1^{\circ}$ in periculo mortis; $2^{\circ}$ extra periculum mortis, dummodo prudenter praevideatur earum rerum condicionem esse per mensem duraturam. $\S 2$. In utroque casu, si praesto est alius sacerdos, ille, si fieri potest, vocetur, ut matrimonium benedicat salva matrimonii validitate coram solis testibus; eisdem in casibus etiam sacerdos acatholicus vocari potest. $\S 3$. Si matrimonium celebratum est coram solis testibus, coniuges a sacerdote quam primum benedictionem matrimonii suscipere ne neglegant". (W niniejszym przypisie celowo zamieszczono wersję łacińską kanonu, gdyż oficjalne tłumaczenie zawiera istotny błąd - brak jest w nim określenia ,prawdziwe małżeństwo”. 
o której w kan. 796 KKKW. Gdyby małżeństwo nie zostało pobłogosławione, małżonkowie powinni jak najszybciej zwrócić się z prośbą o pobłogosławienie małżeństwa do kapłana (nawet niekatolickiego) ${ }^{73}$.

Wnioski de lege ferenda, jakie nasuwają się w związku z opisywanym zagadnieniem, to wyjaśnienie, czy i ewentualnie kiedy strony zawierające związek małżeński - jedynie w obecności dwóch świadków - mają obowiązek skontaktowania się z osobą kompetentną do asystowania przy zawarciu małżeństwa przy użyciu innych dostępnych środków komunikacji - jeśli nie mogą tego uczynić osobiście - bądź za pośrednictwem publicznego operatora pocztowego? Należałoby również wyjaśnić, czy przez możliwość osobistego skontaktowania można rozumieć kontakt ze świadkiem urzędowym za pośrednictwem innej osoby, ale nie wyznaczonej na pełnomocnika?

\section{Extraordinary form of contracting marriage according to Code of Canon Law 1917 and 1983}

Until the Council of Trent for validity of the Marriage no form of its celebration had been required. Although it was not recognized formally in any legal text, the extraordinary form was born with the 1602 Decree. The extraordinary form was comprehensively regulate in decree Ne temere. The legislator in each following code of the canon law published the norm similar to Ne temere decree p. 7-8 which was less restrictive than the previous one.

In the analysis of current law of the Latin Church reference to the previous regulations concerning the subject will give a better grasp on the intentions of the legislator (compare CIC 1983, can. 17, 19). The article tries to answer whether there is a possibility to validly contract the marriage by non-catholics in the extraordinary form in circumstances described in canon 1116 although the proprietary law of the community which they belong to doesn't envisage such possibility. The author in de lege ferenda conclusions sees the necessity to explain whether and when the parties contracting the marriage with two witnesses only are obliged to contact a person competent in assisting to marriage with the use of other available means of communication if they can't do it in person or public post operator.

${ }^{73}$ Por. M. F. Pompedda, De forma celebrationis matrimonii, w: P. V. PInTo (red.), Commento al Codice dei Canoni delle Chiese Orientali, Liberia Editrice Vaticana 2001, s. 713-714. 